\title{
ANALISIS PERLAKUAN AKUNTANSI AKTIVITAS AGRIKULTUR PADA PERUS- AHAAN SEKTOR PERKEBUNAN YANG TERDAPTAR DI BEI MENJELANG PEN- ERAPAN PSAK 69
}

\section{ANALYSIS OF ACCOUNTING TREATMENT OF AGRICULTURAL ACTIVITIES IN THE IDX TARGETED PLANTS SECTOR COMPANIES APPROACHING THE IM- PLEMENTATION OF PSAK 69}

\author{
Muhammad Hidayat ${ }^{1}$ \\ ${ }^{I}$ (Akuntansi, Ekonomi, Universitas Riau Kepulauan, Indonesia) \\ ${ }^{l}$ mhidayatb@fekon.unrika.ac.id
}

\begin{abstract}
Abstrak
Penelitian ini bertujuan untuk mengetahui penerapan PSAK 69 Pertanian (2015) pada laporan keuangan perusahaan industri perkebunan pada periode 2017 pada tahun di mana telah direkomendasikan penerapan awal sebelum efektif pada 1 Januari 2018. Sampel penelitian terdiri dari 8 (delapan) perusahaan perkebunan terdaftar di Bursa Efek Indonesia 2017 diperoleh dengan menggunakan purposive sampling. Penelitian ini menggunakan analisis komparatif deskriptif yaitu dengan membandingkan pernyataan yang ada dalam PSAK 69 dengan penerapannya dalam laporan keuangan. Hasil penelitian ini menunjukkan bahwa 87,5\% atau 7 (tujuh) perusahaan belum menerapkan PSAK 69 Agiriculture, karena tingkat rata-rata penerapan PSAK 69 dalam laporan keuangan ketujuh perusahaan ini hanya mencapai 57\%. Hampir semua perusahaan perkebunan ini belum menggunakan metode nilai wajar untuk mengukur aset biologis tanaman perkebunan mereka dalam laporan keuangan 2017.
\end{abstract}

Kata Kunci ; PSAK 69, IAS 41, Aset Biologis, Produk Pertanian, Nilai Wajar

\begin{abstract}
This study aims to determine the implementation of PSAK 69 Agriculture (2015) on the financial statements of plantation industry companies in the period of 2017 in the year where it has been recommended early implementation before effective on January 1, 2018. Research sample consists of 8 (eight) registered plantation companies in Indonesia Stock Exchange 2017 obtained by using purposive sampling. This study uses descriptive comparative analysis that is by comparing statements that exist in PSAK 69 with its application in the financial statements.The results of this study indicate that $87.5 \%$ or 7 (seven) companies have not applied PSAK 69 Agiriculture, because the average level of application of PSAK 69 in the financial statements of these seven companies only reached $57 \%$. Almost all of these plantation companies have not used the fair value method to measure the biological assets of their plantation crops in the 2017 financial statements
\end{abstract}

Keywords; PSAK 69, IAS 41, Biological Assets, Agricultural Products, Fair Value 


\section{PENDAHULUAN}

Pada industri agribisnis terdapat aktivitas yang unik dibandingkan jenis industri lainnya terutama karena adanya asset biologis, sehingga lahirlah standar akuntansi yang bertujuan untuk mengatur perlakuan akuntansi terhadap aktivitas agrikultur tersebut. IAS 41 yang mengatur akuntansi agrikultur telah diterbitkan oleh Dewan Standar Akuntansi Internasional (IASB) pada tahun 2001 dan telah mengubah akuntansi agrikultur secara global meskipun dalam perjalanannya standar ini telah menimbulkan banyak pertantangan dari beberapa negara, antara lain seperti Malaysia yang keberatan dengan akuntansi terkait bearer asset. Akhirnya pada tahun 2014 IASB telah melakukan amandemen terhadap IAS 41 yang mulai berlaku efektif pada 1 januari 2016. Sebagaimana diketahui Indonesia sebagai anggota Negara G20 telah menyetujui untuk mengadopsi standar akuntansi international. Dalam hal ini Indonesia terlambat melakukan adopsi terhadap IAS41 ini dan baru pada tahun 2015 mengesahkan PSAK 69 Agrikultur yang akan efektif diberlakukan mulai 1Januari 2018.

Keterlambatanini di karenakan Indonesia melihat perkembangan yang ada sehingga menunggu penyelesaian amandemen IAS 41 yang dilakukan oleh IASB. Dengan diterapkannya PSAK 69 ini maka penilaian terhadap asset biologis tidak lagi dilakukan dengan pendekatan biaya, akan tetapi dinilai dengan menggunakan pendekatan nilai wajar. Hal ini didasari dengan pandangan bahwa asset biologis yang dinilai berdasarkan historical cost tidak dapat menggambarkan nilai asset yang sebenarnya karena mengabaikan adanya perubahan nilai dari pertumbuhan dan berkembangan asset biologis tersebut.

Aktivitas agrikultur ini meliputi asset biologis dan produk agrikultur, dimana asset biologis ini bisa berumur singkat kurang dari satu tahun seperti sayuran, tanaman jagung dan lain-lain atau berumur panjang seperti pohon sawit, pohon karet dan lain-lain. Asset biologis juga dapat dibedakan sebagai asset biologis yang dapat menghasilkan produk agrikultur, misalnya pohon sawit menghasilkan buah sawit, sapi menghasilkan susu, diaman buah sawit dan susu tersebut merupakan produk agrikultur. Ada juga asset biologis yang langsung di panen seperti pohon jati yang ditebang untuk dijual sehingga menjadi produk agrikultur.

Sebagai perusahaan yang sudah terdaftar di bursa saham diera globalisasi dengan kemajuan sys- tem informasi dan komunikasi sekarang ini, tentu saja telah mempermudah dan memungkinkan adanya transaksi penjualan saham lintas negara. Dalam menarik minat investor asing tentunya akan lebih baik jika perusahan- perusahaan agribisnis ini dapat menyediakan laporan keuangan yang telah disusun mengacu kepada standard akuntansi keuangan interenasional, karena akan lebih mudah dipahami oleh investor asing.

Adapun yang menjadi rumusan masalah dalam penelitian ini adalah untuk mengetahui bagaimanakah penerapan akuntansi agrikultur pada perusahaan agribisnis yang terdaftar di Bursa Efek Indonesia menjelang diterapkannya PSAK 69 Agrikultur di Indonesia.

\section{Akuntansi Aktivitas Agrikultur}

Pada PSAK 69 disebutkan bahwa Aktivitas agrikultur (agricultural activity) adalah manajemen transformasi biologis dan panen aset biologis oleh entitas untuk dijual atau untuk dikonversi menjadi produk agrikultur atau menjadi aset biologis tambahan. Aset biologis ini adalah aset entitas berupa tanaman dan atau hewan (IAS 41). Sebagaimana asset yang memiliki karakteristik, maka aset biologis ini pun juga merupakan hasil dari transaksi ekonomi entitas di masa lalu, dikendalikan sepenuhnya oleh entitas, dan juga diharapkan akan memberikan manfaat bagi entitas di masa mendatang. Karakteristik khusus yang melekat pada aset biologis terletak pada adanya proses transformasi atau perubahan biologis atas aset ini sampai pada saatnya aset ini dapat dikonsumsi atau dikelola lebih lanjut oleh entitas.

Standar akuntansi keuangan untuk aktivitas agrikultur ini tidak digunakan untuk mengatur asset biologis yang berupa tanaman produktif (bearer plant), adapun yang dimaksud tanaman produktif (bearer plant) menurut PSAK 69 adalah:

a) Tanaman yang dibudidayakan untuk dipanen sebagai produk agrikultur (sebagai contoh, pohon yang ditanam untuk digunakan sebagai potongan kayu);

b) Tanaman yang dibudidayakan untuk menghasilkan produk agrikultur keti- 
ka terdapat kemungkinan yang sangat jarang bahwa entitas juga akan memanen dan menjual tanaman tersebut sebagai produk agrikultur, selain sebagai penjualan sisa insidental (sebagai contoh, pohon yang dibudidayakan baik untuk buahnya maupun potongan kayu); dan

c) Tanaman semusim (annual crops) (sebagai contoh, jagung dan gandum).

Aktivitas agrikultur meliputi berbagai aktivitas seperti: peternakan, kehutanan, tanaman semusim atau tahunan, budidaya kebun dan perkebunan, budidaya bunga, dan budidaya perikanan dan lain-lain.

Terdapat karakteristik umum tertentu dalam keanekaragaman ini:

a) Kemampuan untuk berubah. Hewan dan tanaman hidup mampu melakukan transformasi biologis;

b) Manajemen perubahan. Manajemen mendukung transformasi biologis dengan meningkatkan, atau setidaknya menstabilkan, kondisi yang diperlukan agar proses tersebut dapat terjadi (sebagai contoh, tingkat nutrisi, kelembaban, temperatur, kesuburan, dan cahaya). Manajemen seperti ini membedakan aktivitas agrikultur dari aktivitas lain. Sebagai contoh, proses ganti hasil panen dari sumber yang tidak dikelola (seperti penangkapan ikan laut dan penebangan hutan) bukan merupakan aktivitas agrikultur; dan

c) Pengukuran perubahan. Perubahan dalam kualitas (sebagai contoh, keunggulan genetik, kepadatan, kematangan, kadar lemak, kadar protein, dan kekuatan serat) atau kuantitas (sebagai contoh, keturunan, berat, meter kubik, panjang atau diameter serat, dan jumlah tunas) yang dihasilkan oleh transformasi biologis atau panen diukur dan dipantau sebagai fungsi manajemen yang rutin.

Dari transformasi biologis ini dapat menghasilkan jenis keluaran sebagai berikut:

a) Perubahan aset melalui:

(i) Pertumbuhan (peningkatan kuantitas atau perbaikan kualitas hewan atau tanaman),

(ii) Degenerasi (penurunan kuantitas atau penurunan kualitas hewan atau tanaman),

(iii) Prokreasi (penciptaan hewan atau tanaman hidup tambahan); atau

b) Produksi produk pertanian seperti getah karet, daun teh, wol, dan susu.

\section{Pengakuan dan Pengukuran}

Sebagaimana persyaratan pengakuan asset pada umumnya, maka entitas dapat mengakui aset biologis atau produk agrikultur jika, dan hanya jika:

a) Entitas mengendalikan aset biologis sebagai akibat dari peristiwa masa lalu;

b) Besar kemungkinan manfaat ekonomik masa depan yang terkait dengan aset biologis tersebut akan mengalir ke entitas;

c) Nilai wajar atau biaya perolehan aset biologis dapat diukur secara andal.

Aset biologis diukur pada saat pengakuan awal dan pada setiap akhir periode pelaporan pada nilai wajar dikurangi biaya untuk menjual, kecuali untuk kasus dimana nilai wajar tidak dapat diukur secara andal. Produk agrikultur yang dipanen dari aset biologis milik entitas diukur pada nilai wajar dikurangi biaya untuk menjual pada titik panen. Pengukuran seperti ini merupakan biaya pada tanggal tersebut ketika menerapkan PSAK 14: Persediaan atau Pernyataan lain yang berlaku.

Pengukuran nilai wajar aset biologis atau produk agrikultur dapat didukung dengan mengelompokkan aset biologis atau produk agrikultur sesuai dengan atribut yang signifikan; sebagai contoh, berdasarkan usia atau kualitas. Entitas memilih atribut yang sesuai dengan atribut yang digunakan di pasar sebagai dasar penentuan harga. Entitas seringkali menyepakati kontrak untuk menjual aset biologis atau produk agrikulturnya pada suatu tanggal di masa depan. Harga kontrak tidak selalu relevan dalam mengukur nilai wajar, karena nilai wajar mencerminkan kondisi pasar saat ini dimana pelaku pasar pembeli dan penjual akan melakukan transaksi. Sebagai akibatnya, nilai wajar aset biologis atau 
produk agrikultur tersebut tidak disesuaikan dikarenakan adanya kontrak tersebut.

\section{Keuntungan dan Kerugian}

Keuntungan atau kerugian yang timbul pada saat pengakuan awal aset biologis pada nilai wajar dikurangi biaya untuk menjual dan dari perubahan nilai wajar dikurangi biaya untuk menjual aset biologis dimasukkan dalam laba rugi pada periode dimana keuntungan atau kerugian tersebut terjadi. Kerugian mungkin timbul pada saat pengakuan awal aset biologis, karena biaya untuk menjual dikurangkan dalam menentukan nilai wajar dikurangi biaya untuk menjual aset biologis. Keuntungan mungkin timbul pada saat pengakuan awal aset biologis, seperti ketika anak sapi lahir. Keuntungan atau kerugian yang timbul pada saat pengakuan awal produk agrikultur pada nilai wajar dikurangi biaya untuk menjual dimasukkan dalam laba rugi pada periode dimana keuntungan atau kerugian tersebut terjadi.

\section{Ketidakmampuan untuk Mengukur Nilai Wajar secara Andal}

Terdapat asumsi bahwa nilai wajar aset biologis dapat diukur secara andal. Namun, asumsi tersebut dapat dibantah hanya pada saat pengakuan awal aset biologis yang harga kuotasi pasarnya tidak tersedia dan yang alternatif pengukuran nilai wajarnya secara jelas tidak dapat diandalkan. Dalam kasus tersebut, aset biologis tersebut diukur pada biaya perolehannya dikurangi akumulasi penyusutan dan akumulasi kerugian penurunan nilai. Ketika nilai wajar aset biologis tersebut dapat diukur secara andal, entitas mengukur aset biologis tersebut pada nilai wajarnya dikurangi biaya untuk menjual.

\section{Pengungkapan}

1) Entitas mengungkapkan keuntungan atau kerugian gabungan yang timbul selama periode berjalan pada saat pengakuan awal aset biologis dan produk agrikultur, dan dari perubahan nilai wajar dikurangi biaya untuk menjual aset biologis.

2) Entitas mendeskripsikan setiap kelompok aset biologis. Entitasdianjurkan untuk memberikan deskripsi kuantitatif dari setiap kelompok aset biologis, membedakan antara aset biologis yang dapat dikonsumsi dan aset biologis produktif (bearer biological assets), atau antara aset biologis menghasilkan (mature) dan yang belum menghasilkan (immature), sesuai keadaan aset biologis. Sebagai contoh, entitas dapat mengungkapkan jumlah tercatat aset biologis yang dapat dikonsumsi dan aset biologis produktif berdasarkan kelompok. Entitas selanjutnya dapat membagi jumlah tercatat tersebut antara aset yang telah menghasilkan dan belum menghasilkan. Aset biologis yang dapat dikonsumsi adalah aset biologis yang akan dipanen sebagai produk agrikultur atau dijual sebagai aset biologis. Contoh aset biologis yang dapat dikonsumsi adalah ternak yang dimaksudkan untuk memproduksi daging, ternak yang dimiliki untuk dijual, ikan yang dibudidayakan, tanaman panen seperti jagung dan gandum, produk tanaman produktif dan pohon yang ditanam untuk menghasilkan potongan kayu. Aset biologis produktif adalah aset selain aset biologis yang dapat dikonsumsi; sebagai contoh, ternak yang dimaksudkan untuk memproduksi susu, dan pohon buah yang menghasilkan buah untuk dipanen. Aset biologis produktif bukan merupakan produk agrikultur, tetapi dimiliki untuk menghasilkan produk agrikultur. 45. Aset biologis dapat diklasifi kasikan baik sebagai aset biologis menghasilkan maupun belum menghasilkan. Aset biologis menghasilkan adalah aset yang telah mencapai spesifi kasi untuk dipanen (untuk aset biologis yang dapat dikonsumsi) atau mampu menghasilkan panen yang berkelanjutan (untuk aset biologis produktif).

3) Jika tidak diungkapkan di bagian manapun dalam informasi yangdipublikasikan bersama dengan laporan keuangan, maka entitas mendeskripsikan:

a) Sifat aktivitasnya yang melibatkan setiap kelompok aset biologis; 
b) Ukuran atau estimasi nonkeuangan dari kuantitas fisik:

- $\quad$ setiap kelompok aset biologis milik entitas pada akhir periode;

- keluaran produk agrikultur selama periode tersebut.

4) Entitas mengungkapkan:

a) Keberadaan dan jumlah tercatat aset biologis yang kepemilikannya dibatasi, dan jumlah tercatat aset biologis yang dijaminkan untuk liabilitas;

b) Jumlah komitmen untuk pengembangan atau akuisisi aset biologis;

c) Strategi manajemen risiko keuangan yang terkait dengan aktivitas agrikultur.

5. Entitas menyajikan rekonsiliasi perubahan jumlah tercatat aset biologis antara awal dan akhir periode berjalan. Rekonsiliasi tersebut mencakup:

a. keuntungan atau kerugian yang timbul dari perubahan nilai wajar dikurangi biaya untuk menjual;

b. kenaikan karena pembelian;

c. penurunan yang diatribusikan pada penjualan dan aset biologis yang diklasi_ kasikan sebagai dimiliki untuk dijual (atau termasuk dalam kelompok pelepasan yang diklasi_kasikan sebagai dimiliki untuk dijual) sesuai dengan PSAK 58;

d. penurunan karena panen;

e. kenaikan yang dihasilkan dari kombinasi bisnis;

f. selisih kurs neto yang timbul dari penjabaran laporan keuangan ke mata uang penyajian yang berbeda, dan penjabaran dari kegiatan usaha luar negeri ke mata uang penyajian entitas pelapor; dan

g. perubahan lain.

6. Aktivitas agrikultur sering terekspos oleh iklim, penyakit, dan risiko alam lain. Jika suatu peristiwa terjadi sehingga menimbulkan suatu pos pendapatan atau beban yang material, maka sifat dan jumlah pendapatan dan beban tersebut diungkapkan sesuai dengan PSAK 1: Penyajian Laporan Keuangan. Contoh dari peristiwa tersebut termasuk wabah penyakit mematikan, banjir, kekeringan atau pembekuan yang parah, dan wabah serangga.
7. Pengungkapan Tambahan untuk Aset Biologis yang Nilai Wajarnya Tidak Dapat Diukur secara Andal sehingga entitas mengukur aset biologis pada biaya perolehan dikurangi akumulasi penyusutan dan akumulasi kerugian penurunan nilai pada akhir periode, maka entitas mengungkapkan untuk aset biologis tersebut:

a. deskripsi dari aset biologis tersebut;

b. penjelasan tentang mengapa alasan nilai wajar tidak dapat diukur secara andal;

c. jika memungkinkan, rentang estimasi dimana nilai wajar kemungkinan besar berada;

d. metode penyusutan yang digunakan;

e. umur manfaat atau tarif penyusutan yang digunakan;

f. jumlah tercatat bruto dan akumulasi penyusutan (digabungkan dengan akumulasi kerugian penurunan nilai) pada awal dan akhir periode.

\section{METODOLOGI}

\section{Jenis Penelitian}

Jenis penelitian ini adalah penelitian kualitatif dengan menggunakan metode komparatif yaitu dengan mempelajari penerapan akuntansi aktivitas agrikultur pada laporan keuangan perusahaan - perusahaan sektor agribisnis yang terdaftar di Bursa Efek Indonesia pada periode yang berakhir pada 31 Desember 2017 dan membandingkan dengan PSAK 69 Agrikultur yang telah diterbitkan pada tahun 2016.

\section{Populasi dan Sample}

Populasi dalam penelitian ini adalah seluruh perusahaan perkebunan yang terdaftar pada Bursa Efek Indonesia pada tahun 2017. Sample ditentukan dengan menggunakan purposive sampling yaitu dengan menetapkan kriteria sebagai berikut: 
1. Perusahaan sektor industri perkebunan yang terdaftar pada Bursa Efek Indonesia pada tahun 2016 - 2017

2. Perusahaan yang telah mempublikasikan laporan keuangan lengkan untuk tahun buku 2017

3. Laporan keuangan telah di audit oleh kantor akuntansi public

\section{Pengumpulan Data}

Data yang digunakan dalam penelitian ini adalah data sekunder berupa laporan keuangan perusahaan pada sektor industry agribisnis yang terdaftar di BEI tahun 2017. Pengumpulan data dilakukan dengan mengunduh secara lansung melalui website resmi Bursa Efek Indonesia pada www.idx.co.id

\section{Metode Analisis}

Dalam metode ini analisis data dilakukan dengan analisis komparatif, yatitu analisis yang digunakan untuk membandingkan persamaan dan perbedaan antara dua atau lebih fakta - fakta dan sifat - sifat objek yang diteliti berdasarkan kerangka pemikiran tertentu. Dalam hal ini analisis dilakukan dengan melakukan perbandingan PSAK 69 Agrikultur yang meliputi bagaimana dilakukannya pengakuan, pengukuran dan pengungkapan dan bagaimana penerapannya di dalam laporan keuangan perusahaan pada industri perkeunan yang terdapat di BEI tahun 2007.

\section{PEMBAHASAN}

\section{Data Sample Penelitian}

Pada table 1 berikut ini dapat dilihat data perusahaan yang menjadi sampel

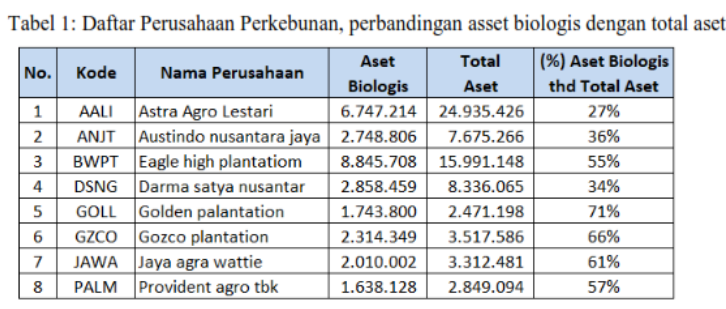

\section{Analisis Data}

Berikut ini adalah analisis komparatif yang dilakukan dengan menggunakan table indikator penilaian terhadap penerpan PSAK 69, dimana perusahaan yang telah menerapkan masing-masing indicator
Tabel 2 Komparasi Laporan Keuangan Perkebunan di BEI dengan PSAK 69

\begin{tabular}{|c|c|c|c|c|c|c|c|c|c|}
\hline & Indikator Penilaian & \multicolumn{7}{|c|}{ Kode Perusahaan } & \\
\hline & PSAK 69 Agrikultur & \begin{tabular}{l|l|}
$\mathrm{A}$ & $\mathrm{A}$ \\
$\mathrm{A}$ & $\mathrm{N}$ \\
$\mathrm{L}$ & $\mathrm{J}$ \\
$\mathrm{I}$ & $\mathrm{T}$ \\
\end{tabular} & \begin{tabular}{l|}
$\mathrm{B}$ \\
$\mathrm{W}$ \\
$\mathrm{P}$ \\
$\mathrm{T}$
\end{tabular} & \begin{tabular}{l|l}
$\mathbf{D}$ \\
$\mathbf{S}$ \\
$\mathbf{N}$ \\
$\mathbf{G}$
\end{tabular} & \begin{tabular}{l|l}
$\mathbf{G}$ & \\
$\mathbf{O}$ & \\
$\mathrm{L}$ & \\
$\mathrm{L}$ & \\
\end{tabular} & \begin{tabular}{l|}
$\mathbf{G}$ \\
$\mathrm{Z}$ \\
$\mathbf{C}$ \\
$\mathbf{O}$
\end{tabular} & \begin{tabular}{l|}
$\mathbf{J}$ \\
$\mathrm{A}$ \\
$\mathbf{W}$ \\
$\mathrm{A}$
\end{tabular} & $\begin{array}{l}\mathrm{P} \\
\mathrm{A} \\
\mathrm{L} \\
\mathrm{M} \\
\end{array}$ & \\
\hline \multicolumn{9}{|c|}{$\begin{array}{l}\text { A. Pengakuan } \\
\text { Entitas mengakui aset biologis atau produk agrikultur ketika, } \\
\text { dan hanva ketika: }\end{array}$} & \\
\hline 1 & $\begin{array}{l}\text { Nilai wajar atau biaya perolehan aset biologis dapat } \\
\text { diukur secara andal. }\end{array}$ & \begin{tabular}{l|l}
1 & 1
\end{tabular} & 1 & \begin{tabular}{l|}
1 \\
\end{tabular} & \begin{tabular}{|l|l}
1 \\
\end{tabular} & 1 & 1 & 1 & \\
\hline 2 & \begin{tabular}{l|l} 
Besar kemungkinan manfaat ekonomik masa depan \\
yang terkait dengan aset biologis tersebut akan \\
mengalir ke entitas;
\end{tabular} & \begin{tabular}{l|l}
1 & 1
\end{tabular} & 1 & 1 & 1 & 1 & 1 & 1 & \\
\hline 3 & \begin{tabular}{l|l}
$\begin{array}{l}\text { Entitas mengendalikan aset biologis sebagai akibat } \\
\text { dari peristiwa masa lalu; }\end{array}$ & \\
\end{tabular} & \begin{tabular}{l|l}
1 & 1 \\
\end{tabular} & 1 & 1 & 1 & 1 & 1 & 1 & \\
\hline \multicolumn{9}{|c|}{ B. Pengukuran } & \\
\hline 1 & $\begin{array}{l}\text { Aset biologis diukur pada saat pengakuan awal dan } \\
\text { pada setiap akhir periode pelaporan pada nilai wajar } \\
\text { dikurangi biaya untuk menjual, kecuali untuk kasus } \\
\text { yang dideskripsikan dalam paragraf } 30 \text { dimana nilai } \\
\text { wajar tidak dapat diukur secara andal }\end{array}$ & \begin{tabular}{l|l}
0 & 0
\end{tabular} & 0 & 0 & 0 & 1 & 0 & 0 & \\
\hline 2 & $\begin{array}{l}\text { Produk agrikultur yang dipanen dari aset biologis } \\
\text { milik entitas diukur pada nilai wajar dikurangi biaya } \\
\text { untuk menjual pada titik panen. Pengukuran seperti } \\
\text { ini merupakan biaya pada tanggal tersebut ketika } \\
\text { menerapkan PSAK 14: Persediaan atau Pernyataan } \\
\text { lain yang berlaku }\end{array}$ & \begin{tabular}{l|l}
0 & 0
\end{tabular} & 0 & 0 & 0 & 1 & 0 & 0 & \\
\hline \multicolumn{9}{|c|}{ C. Pengungkapan } & \\
\hline 1 & $\begin{array}{l}\text { Entitas mengungkapkan keuntungan atau kerugian } \\
\text { gabungan yang timbul selama periode berjalan pada } \\
\text { saat pengakuan awal aset biologis dan produk } \\
\text { agrikultur, dan dari perubahan nilai wajar dikurangi } \\
\text { biaya untuk menjual aset biologis. }\end{array}$ & \begin{tabular}{l|l}
0 & 0
\end{tabular} & 0 & 0 & 0 & 1 & 0 & 0 & \\
\hline 2 & $\begin{array}{l}\text { Entitas mendeskripsikan setiap kelompok aset } \\
\text { biologis. Entitas dianjurkan untuk memberikan } \\
\text { deskripsi kuantitatif dari setiap kelompok aset } \\
\text { biologis, membedakan antara aset biologis yang dapat } \\
\text { dikonsumsi dan aset biologis produktif (bearer } \\
\text { biological assets), atau antara aset biologis } \\
\text { menghasilkan (mature) dan yang belum } \\
\text { menghasilkan (immature), sesuai keadaan aset } \\
\text { biologis. }\end{array}$ & \begin{tabular}{l|l}
1 & 1
\end{tabular} & 1 & 1 & 1 & 1 & 1 & 1 & \\
\hline \multirow[t]{3}{*}{3} & $\begin{array}{l}\text { Jika tidak diungkapkan di bagian manapun dalam } \\
\text { informasi yang dipublikasikan bersama dengan } \\
\text { laporan keuangan, maka entitas mendeskripsikan: }\end{array}$ & & & & & & & & \\
\hline & \begin{tabular}{llll|} 
b. Sifat aktivitasnya yang melibatkan setiap \\
kelompok aset biologis;
\end{tabular} & 0 & 0 & 0 & 0 & 1 & 0 & 0 & \\
\hline & $\begin{array}{l}\text { c. Ukuran atau estimasi nonkeuangan dari kuantitas } \\
\text { fisik: } \\
\text { - Setiap kelompok aset biologis milik entitas pada } \\
\text { akhir periode; } \\
\text { - keluaran produk agrikultur selama periode } \\
\text { tersebut. }\end{array}$ & 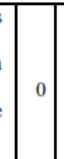 & 0 & 0 & 0 & 0 & 1 & 0 & 0 \\
\hline 4 & $\begin{array}{l}\text { Entitas mengungkapkan strategi manajemen risiko } \\
\text { keuangan yang terkait dengan aktivitas agrikultur. }\end{array}$ & 0 & 0 & 0 & 0 & 0 & 0 & 0 & 0 \\
\hline 5 & $\begin{array}{l}\text { Entitas menyajikan rekonsiliasi perubahan jumlah } \\
\text { tercatat aset biologis antara awal dan akhir periode } \\
\text { berjalan. }\end{array}$ & 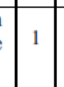 & 1 & 1 & 1 & 1 & 1 & 1 & 1 \\
\hline \multirow[t]{5}{*}{6} & $\begin{array}{l}\text { Jika entitas mengukur asset biologis pada biaya } \\
\text { perolehan dikurangi akumulasi penyusutan dan } \\
\text { akumulasi kerugian penurunan nilai pada akhir } \\
\text { periode maka entitas mengungkapkan untuk asset } \\
\text { biologis tersebut: }\end{array}$ & & & & & & & & \\
\hline & Deskripsi dari asset biologis tersebut & 1 & 1 & 1 & 1 & 1 & 1 & 1 & 1 \\
\hline & $\begin{array}{l}\text { Penjelasan tentang mengapa nilai wajar tidak dapat } \\
\text { diukur secara handal }\end{array}$ & 0 & 0 & 0 & 0 & 0 & 0 & 0 & 0 \\
\hline & Umur manfaat atau tariff penyusutan yang digunakan & 1 & 1 & 1 & 1 & 1 & 1 & 1 & 1 \\
\hline & $\begin{array}{l}\text { Jumlah tercatat bruto dan akumulasi penyusutan } \\
\text { digabung dengan akumulasi rugi penurunan nilai } \\
\text { pada awal dan akhir periode. }\end{array}$ & 1 & 1 & 1 & 1 & 1 & 1 & 1 & 1 \\
\hline & PENERAPAN (\%) & 57 & 57 & 57 & 57 & 57 & 92 & 57 & 57 \\
\hline
\end{tabular}

Dari tabel 2 diatas dapat menjelaskan bahwa perusahaan disektor idustri perkebunan yang terdaftar di BEI jika dilihat dari laporan keuangan tahun 2017 yaitu pada priode satu tahun sebelum PSAK 69 Agrikultur diwajipkan penerapannya dimana dapat disimpulkan bahwa baru $12,5 \%$ perusahaan atau hanya ada 1 (satu) perusahaan yang telah menerapkan PSAK 69 dari total 8 (delapan) perusahaan yang 
menjadi sampel dalam penelitian ini. Adapun tingkat penerapan PSAK 69 pada tingkat 57\% ini adalah merupakan penerpan PSAK 16 tentang asset tetap yang secara umum masih digunakan sebagai pedoman dalam pencatatan tansaksi asset tetap biologis yaitu asset tanaman perkebunan dimana terdapat beberapa kesamaan.

\section{a. Pengakuan dan Pengukuran}

Sebagaimana syarat pengakuan asset tetap tidak ada perbedaan dengan syarat pengakuan asset biologis maka dalam hal pengakuan bukanlah merupakan suatu permasalahan dengan diterbitkannya standar agrikultur ini. Menurut PSAK 69 Entitas mengakui aset biologis atau produk agrikultur ketika, dan hanya ketika Nilai wajar atau biaya perolehan aset biologis dapat diukur secara andal dan besar kemungkinan manfaat ekonomik masa depan yang terkait dengan aset biologis tersebut akan mengalir ke entitas, serta entitas mengendalikan aset biologis sebagai akibat dari peristiwa masa lalu.

\section{b. Pengukuran}

Secara umumnya perusahaan perkebunana yang terdaftar di BEI pada tahun 2017 mencatat asset biologis berupa tanaman perkebunan dikelompokan menjadi dua jenis yaitu tanaman belum menghasilkan dan tanaman menghasilkan.

1) Tanaman Belum Menghasilkan Tanaman belum menghasilkan diakui sebesar harga perolehan yang merupakan akumulasi biaya yang terjadi sebelum tanaman tersebut menghasilkan dan dipanen. Biaya-biaya tersebut mencakup biaya untuk pembibitan, persiapan lahan, penanaman, pemupukan, pemeliharaan, biaya bunga atas pinjaman bank yang diperoleh untuk membiayai pengembangan tanaman sampai menghasilkan, dan alokasi biaya tidak langsung lainnya berdasarkan luas tanah yang ditanami. Biaya-biaya ini diakumulasikan sampai saat tanaman siap untuk dipanen, selama nilai tercatat tanaman belum menghasilkan tidak melebihi nilai tertinggi antara nilai penggantiandan jumlah yang dapat dipulihkan. Biayabiaya yang terjadi untuk pembibitan, pembelian bibit dan pemeliharaannya dinyatakan sebesar biaya perolehan. Akumulasi biaya ini akan dipindahkan keakun "Tanaman belum menghasilkan" pada saat siap ditanam.
2) Tanaman Menghasilkan Tanaman menghasilkan diukur pada biaya perolehan setelah dikurangi akumulasi penyusutan dan akumulasi rugi penurunan nilai. Penyusutan asset tanaman diukur dengan sebagai beban produksi atau penambahan biaya perolehan yang dihasilkan dan akumulasi penyusutan/amortisasi aset tanaman disajikan sebagai pos pengurang jumlah yang tercatatnya dan dilakukan pada saat tanaman sudah menghasilkan. Tanaman menghasilkan juga mengalami penurunan nilai, dalam hal ini penurunan nilainya diakui sebagai kerugian pada periode terjadinya. Tanaman menghasilkan diakumulasikan kerugian dari operasi yang berkelanjutan, jika ada, diakui sebagai laba atau rugi seseui dengan kategori biaya yang konsisten dengan fungsi dari aset yang diturunkan nilainya. Penilaian dilakukan pada akhir setiap tanggal pelaporan untuk menilai apakah terdapat indikasi bahwa penurunan nilai yang diakui dalam periode sebelumnya mungkin tidak ada lagi atau mungkin menurun. Jika indikasi dimaksud ditemukan, maka entitas mengestimasi jumlah terpulihkan aset. Kerugian penurunan nilai yang telah diakui dalam periode sebelumnya dibalik hanya jika terdapat perubahan asumsi-asumsi terpulihkan aset tersebut sejak rugi penurunan nilai terakhir diakui. Akumulasi penurunan nilai asset tanaman disajikan sebagai pos lawan jumlah tercatatanya, pemulihan penurunan nilai diakui sebagai keuntungan. Keuntungan dan kerugian yang terjadi pada perusahaan diakui sebgai periode terjadinya, keuntungan dan kerugian tersebut disajikan sebagai pendapatan dan beban nonusaha. Aset menghasilkan disajikan pada neraca dalam kelompok aset tidak lancar.

\section{c. Pengungkapan}


Pada laporan keuangan industri perkebunaan tahun 2017 tersebut telah dilakukan pendeskripsian setiap kelompok aset biologis, dimana entitas memberikan deskripsi kuantitatif dari setiap kelompok aset biologis. Perusahaan juga telah membedakan antara aset biologis yang dapat dikonsumsi dan aset biologis produktif (bearer biological assets), atau antara aset biologis menghasilkan (mature) dan yang belum menghasilkan (immature), sesuai keadaan aset biologis. Pengungkapan kebijakan akuntansi signifikan yang digunakan perusahaan telah menguraikan tentang metode pengakuan dan pengukuran aset perkebunan. Sehingga dalam hal ini perusahaan telah mengungkapkan dengan jelas tentang umur manfaat atau tarif penyusutan yang digunakan pada pencatatan asset perkebunan. Demikian juga teleah diungkapkan Jumlah tercatat bruto dan akumulasi penyusutan digabung dengan akumulasi rugi penurunan nilai pada awal dan akhir periode pelaporan.

\section{KESIMPULAN}

Dari pembahasan yang terlah disampaikan sebelumnya maka dapat disimpulkan sebagai berikut:

a. Pengakuan asset tetap biologis tanaman perkebunan tidak ada perbedaan pengaturan baik pada PSAK 69 maupun sebelum diterbitkannya PSAK 69 Agrikultur. Hal ini dikarenakan syarat pengakuan asset tetap biologis tidak berbeda dengan pengakuan asset tetap yang diatur pada PSAK 16 Aset Tetap. Sehingga dapat disimpulkan bahwa pengakuan asset tetap biologis pada laporan keuangan tahun 2017 perusahaan sektor industri perkebunan yang terdaftar di BEI telah dilakukan sesuai dengan yang diatur dalam PSAK 69.

c. Asset tetap biologis pada laporan keuangan tahun 2017 pada perusahaan industri perkebunan yang terdaftar di BEI secara umum masih diukur dengan menggunakan biaya perolehan setelah dikurangi akumulasi penyusutan dan akumulasi rugi penurunan nilai. Sedangkan menurut PSAK 69 aset tetap biologis diukur pada saat pengakuan awal dan pada setiap akhir periode pelaporan pada nilai wajar dikurangi biaya untuk menjual. Sehingga dapat disimpulkan bahwa secara umum metode pengukuran belum dilakukan sesuai yang diatur dalam PSAK 69. Kecuali hanya satu perus- ahaan dari total 8 (delapan) perusahaan yang menjadi sampel penelitian yang telah menerapkan pengukuran asset tetap biologis dengan menggunakan nilai wajar yaitu PT.Gozco Plantation.

c. Pengungkapan

Pengungkapan belum dilakukan dengan sepenuhnya sesuai dengan yang disyaratkan PSAK 69 kecuali untuk deskripsi asset biologis, pengungkapan umur manfaat atau tariff penyusutan yang digunakan dan pengungkapan terhadap jumlah tercatat bruto, dan akumulasi penyusutan digabung dengan akumulasi rugi penurunan nilai pada awal dan akhir periode. Secara umum laporan keuangan tahun 2017 pada perusahaan industri perkebunan yang terdaftar di BEI diungkapkan bahwa PSAK 69 ini belum diterapkan pada laporan keuangan tahun 2017 sehingga tidak ada penjelasan mengapa asset tetap biologis tidak diukur pada nilai wajar.

Sedangkan perbedaan yang cukup mendasar adalah belum diterapkannya pengukuran asset tetap perkebunan dengan menggunakan nilai wajar.

\section{DAFTAR PUSTAKA}

Farida, I. (2013). Analisis Perlakuan Akuntansi Aset Biologis Berdasarkan International Accounting Standard 41 pada PT. Perkebunan Nusantara VII (Persero). Surabaya. Universitas Negeri Surabaya.

Feleagă, Liliana at.all. 2012. Theoretical considerations about implementation of IAS 41 in Romania. Theoretical and Applied Economics Volume XIX (2012), No. 2(567), pp. 31-38.

Gonçalves, Rute and Patrícia Lopes. 2014. Accounting in Agriculture: Disclosure Practices of Listed Firms Rute . FEPUP, n.30 March 2014 ISSN: 08708541., School of Economics and 
Management, University of Porto.

Hasmi, Nurlaila. 2013. "Penilaian Aset Bologis: Implikasi Penerapan Internasional Accounting Standard (IAS) 41 Pada PT Perkebunan Nusantara XIV Makassar (Persero)".

Skripsi Universitas Islam Negeri (UIN) Alauddin Makassar.

Ikatan Akuntansi Indonesia. 2015. "Pernyataan Standar Akuntansi Keuangan (PSAK) No. 69. Agricultur". Jakarta.

Ikatan Akuntan Indonesia. 2015. "Per nyataan Standar Akuntansi Keuangan (PSAK) No.14 Persediaan". Jakarta
Mates, Dorel at.all. 2015. "Biological assets and the agricultural products in the context of the imlementation of the ias 41: a case study of the Romanian agro-food system". DOI:10.2298/ABS140301042M

Arch. Biol. Sci., Belgrade, 67(2), 705-714, 2015

Suhaemi. 2016. Analisis Implementasi Internasional Aaccounting Standards (IAS) 41 terkait penilaian aset biologis pada PT PP London Sumatera Indonesia Tbk.Skripsi Universitas Islam Negaeri Alauddin Makassa 